\title{
Origins and relationships of native populations of Salmo trutta (brown trout) in Spain
}

\author{
J. L. GARCÍA-MARÍN* \& C. PLA \\ Laboratori d'Ictiologia, F.C.E. Universitat de Girona, Plaça Hospital 6, E-17071-Girona, Spain
}

\begin{abstract}
Allele frequency variation at 25 protein-coding loci was compared among collections from 24 naturally spawning brown trout populations in Spain. Evidence of introgression was apparent but alleles of indigenous fish predominated in each of the nine populations sampled in areas where exogenous hatchery fish had been released. Native Spanish gene pools were characterized by strong individuality based on distinct allele frequencies of both adjacent and distant rivers $\left(G_{\mathrm{ST}}=0.64\right)$, the locally high frequency of rare and previously unreported alleles, and low heterozygosities $\left(H_{\mathrm{S}}=0.031\right)$. Two major Spanish lineages are proposed within a previously postulated 'ancestral' grouping of populations existing in southern Europe, based on predominant alleles at the $C K-A 1$ * locus. An 'Atlantic' group (comprising populations in Atlantic flowing streams) extends to unglaciated areas of the southern British Isles and Britanny, and is characterized by high frequencies of the *115 allele. Mediterranean flowing streams are populated by a 'Mediterranean' group extending eastward through the Caspian basin and characterized by high frequencies of the $* 100$ allele.
\end{abstract}

Keywords: brown trout, evolution, isozymes, Salmo trutta.

\section{Introduction}

The evolution and often coexistence of multiple ecological and morphological varieties of brown trout, Salmo trutta, have confused the taxonomy of the species throughout its native Eurasian distribution, as reflected in now obsolete designations such as $S$. trutta trutta for anadromous and $S$. trutta fario for freshwater varieties (Behnke, 1986). A better understanding of ancestral groupings of brown trout arose following development of biochemical and molecular methods for identifying allelic variations at multiple defined loci (e.g. Ferguson, 1989; Skaala \& Nævdal, 1989; Karakousis \& Triantaphyllidis, 1990; Hindar et al., 1991). However, disproportionate sampling of more northern areas has limited possible conclusions about inferred relationships of brown trout at the species level based on the accumulation of biochemical genetic information throughout the species range. Two major groups, distinguished primarily by different common alleles at the $L D H-C^{*}$ locus, have indicated distinct southern ('ancestral') and northern ('modern') populations (Hamilton et al., 1989). Despite the clarity of

*Correspondence. this separation, much uncertainty persists about the underlying evolutionary history because of limited sampling of southern populations. For example, previous studies of Spanish wild populations were restricted to small areas or few collection sites (García-Marín et al., 1991; Martinez et al., 1993; Morán et al., 1995).

This study's purpose is to understand better relationships among indigenous Spanish brown trout. Based on variation at 25 polymorphic protein-coding loci, we identify introgression from exogenous ('modern') populations, and tentatively distinguish two subgroups within the 'ancestral' grouping. The implications of these observations to the pre- and postglacial history of brown trout are discussed.

\section{Materials and methods}

\section{Samples}

Brown trout were collected between 1988 and 1992 from 24 Atlantic and Mediterranean drainages throughout the Iberian Peninsula (Fig. 1). The primary criterion for collection locations was the likelihood (based on discussions with management personnel in the sampled areas) that populations 
represented descendents of indigenous rather than introduced hatchery fish of exogenous origins. Legal limitations restricted sample sizes to a maximum of 25 individuals per collection, and numbers of some collections were further restricted by the availability of fish. Sampling was by electrofishing within a linear distance not less than $400 \mathrm{~m}$ upstream. Following collection, fish were immediately frozen on dry ice, and were transferred to a $-80^{\circ} \mathrm{C}$ freezer in the laboratory.

\section{Electrophoresis}

Electrophoretic procedures including tissue extraction from skeletal muscle, liver and eye and visualization of enzyme activity were as described in García-Marín et al. (1991). Nomenclature for the designation of loci and alleles follows Shaklee et al. (1990). The activities of 33 enzymes resolved gene products of 49 loci (Enzyme Commission number and loci in parentheses): acid phosphatase (3.1.3.2, $\left.A C P^{*}\right)$, aconitate hydratase (4.2.1.3, $\left.A H-2^{*}\right)$, alcohol dehydrogenase (1.1.1.1, $\left.A D H^{*}\right)$, aspartate aminotransferase $\left(2.6 .1 .1, \quad s A A T-4^{*}\right)$, creatine kinase (2.7.3.2, $\left.C K-A 1^{*},-A 2^{*}\right)$, esterase (3.1.1.1, EST-1*, $-2 *)$, fumarate hydratase $\left(4.2 .1 .2, F H-3^{*}\right), \beta$ - N-acetylgalactosaminidase $\left(3.2 .1 .53, b G A L A-2^{*}\right)$, N-acetyl$\beta$-glucosaminidase $\left(3.2 .1 .52, b G L U A^{*}\right)$, glucose- 6-phosphate isomerase (5.3.1.9, GPI- $\left.A^{*},-B 1^{*},-B 2^{*}\right)$, $\beta$-glucuronidase $\left(3.2 .1 .31, b G U S-2^{*}\right)$, glutamate dehydrogenase (1.4.1.2, GLUDH*), glyceraldehyde3-phosphate dehydrogenase (1.2.1.12, GAPDH-1*, -2*, $\left.-3^{*}\right)$, glycerate dehydrogenase (1.1.1.29, GLYDH*), glycerol-3-phosphate dehydrogenase $(1.1 .1 .8, G 3 P D H$ $\left.2^{*}\right)$, guanine deaminase $\left(3.5 .4 .3, G D A^{*}\right)$, hydrogen peroxide oxidoreductase $\left(1.11 .1 .7, P O D^{*}\right)$, isocitrate dehydrogenase $\left(1.1 .1 .42, I D H P-1 *,-2^{*},-3^{*}\right)$, L-lactate dehydrogenase (1.1.1.27, $L D H-A 1^{*},-A 2^{*},-B 2^{*}$, $\left.-C^{*}\right)$, lactoylglutathione lyase (4.4.1.5, $\left.L G L^{*}\right), \alpha-$ mannosidase (3.2.1.24, $\left.a M A N^{*}\right)$, malate dehydrogenase (1.1.1.37, $\left.s M D H-A 1^{*},-A 2^{*},-B 1,2^{*}\right)$, malic enzymeNAD (1.1.1.39, $\left.M E^{*}\right)$, malic enzyme-NADP (1.1.1.40, $\left.M E P-1^{*},-2^{*},-3^{*}\right)$, mannose-6-phosphate isomerase (5.3.1.8, MPI-2*), peptidase leucine-tyrosine (3.4.11.-, PEPLT*), proline dipeptidase (phenylalanine-proline) (3.4.13.9, $\left.P E P P A P^{*}\right)$, dipeptidase (valineleucine) (3.4.13.*, $P E P V L^{*}$ ), tripeptidase (leucylglycyl-glycine) (3.4.11.4, PEPLGG*), phosphoglucomutase (5.4.2.2, $\left.P G M-1^{*}\right), \quad$ 6-phosphogluconate dehydrogenase $\left(1.1 .1 .44, P G D H-1^{*}\right)$, superoxide dismutase (1.15.1.1, $\left.S O D-1^{*}\right)$, xanthine oxidase (1.1.3.22, $\left.X O^{*}\right)$.

Most loci were codominantly expressed, permitting direct counts of allele frequencies from gel phenotypes. Frequencies for the $L D H-A 2 * 100 Q L$ allele, described in greater detail in the results, were

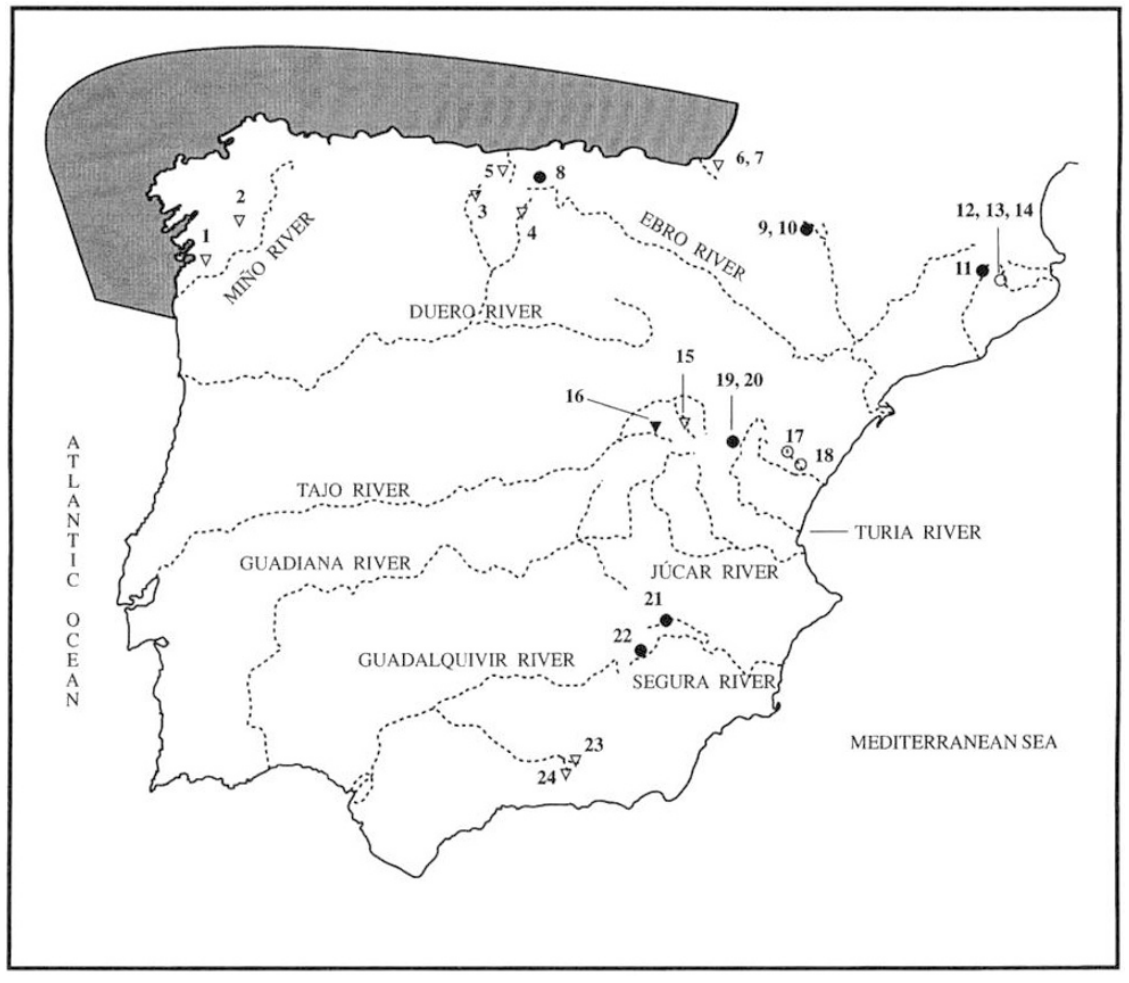

Fig. 1 Geographical locations of rivers and streams where brown trout were sampled, and the main river systems in the Iberian Peninsula (Guadiana and Júcar rivers were not sampled). Darkened portion in the Atlantic ocean represents the area where anadromous fish are present. Map codes correspond to streams: (1) Tea, (2) Bubal, (3) Carrión, (4) Pisuerga, (5) Vendúl, (6) Gorrotola, (7) Santolatz, (8) Guares, (9) Ordisa, (10) Otal, (11) Riutort, (12) Ter, (13) Nuria, (14) Massanes, (15) Hoceseca, (16) Valsalobre, (17) Linares, (18) Villahermosa, (lower part of the Linares stream), (19) Guadalaviar, (20) Noguera, (21) Madera, (22) Mundo, (23) Genil and (24) Dilar. Symbols: $O$ Mediterranean flowing river, $\nabla$ Atlantic flowing river. Filled symbol means potential presence of hatchery fish in the sampled area as indicated by forestry guards or presence of the $L D H-C * 90$ allele. 
estimated by the square root of the homozygous phenotypes, assuming Hardy-Weinberg equilibrium. Allele frequencies for the isoloci $s M D H-B 1,2 *$ were allocated to individual loci, $s M D H-B 1^{*}$ and $s M D H$ $B 2 *$. All variation of the $* 80$ allele was assigned to the $S M D H-B 1 *$ locus, and frequencies were estimated from the square root of the homozygous *100/100 phenotypes, assuming Hardy-Weinberg equilibrium. Frequencies of the $* 75$ allele could be calculated directly from electrophoretic phenotypes and were assigned to either the $s M D H-B 1^{*}$ or the $s M D H-B 2 *$ loci as indicated in Fig. 2.

\section{Data analysis}

Phenotypic distributions of all codominantly expressed loci were tested for agreement with Hardy-Weinberg expectations by the exact probabilities test (Hernández \& Weir, 1989). For loci with more than two alleles, the variant alleles were lumped; such lumping was required for only four (three triallelic and one tetra-allelic) out of 140 tests. Allele frequency differences among samples were tested by contingency chi-square analysis (Sokal \& Rohlf, 1981). The sequential Bonferroni technique (Rice, 1989) was used to adjust significance levels for multiple simultaneous comparisons. To test for random mating in populations introgressed with hatchery fish, a study of pairwise gametic phase equilibria involving alleles of hatchery and indigenous origin was made using Burrow's disequilibrium parameter $D$ (Campton, 1987).

Hierarchical gene diversity analysis (Nei, 1973; Chakraborty et al., 1982) was used to partition the total genetic variation $\left(H_{\mathrm{T}}\right)$ into its components within streams $\left(H_{\mathrm{S}}\right)$, between streams within the main river $\left(G_{\mathrm{SR}}\right)$, between rivers within the drainage
$\left(G_{\mathrm{RD}}\right)$, and between Atlantic and Mediterranean drainages $\left(G_{\mathrm{DT}}\right)$. Pairwise multilocus comparisons between samples were calculated by Nei's measure of genetic identity and its associated genetic distance (Nei, 1972). A dendrogram was constructed by the unweighted pair-group method with arithmetic averages (UPGMA, Sneath \& Sokal, 1973) from the matrix of distances; confidence of the branching points was estimated by bootstrapping of the polymorphic loci over 1000 replicates. In addition, patterns of variation were assessed from the matrix of identities (rather than the non-Euclidean distance measure) by a principal coordinate analysis (Gower, 1966).

\section{Results}

\section{Interpreting $\mathrm{LDH}-\mathrm{A} 2 *$ variation}

We observed variation of LDH patterns from muscle extracts involving a reduced intensity of the homomeric band for $L D H-A 2^{*}$ (Fig. 3, phenotypes b). Similar variation has previously been described in populations from Greece by Karakousis \& Triantaphyllidis (1990), who interpreted the variant phenotype to reflect individuals heterozygous for a null allele at the $L D H-A 2^{*}$ locus. The high frequency of this phenotype ( $>90$ per cent) in some Spanish samples considerably exceeds expectations of heterozygotes under Hardy-Weinberg equilibrium, and has forced us to consider an alternate explanation. We therefore interpret the $b$ phenotypes in Fig. 3 to be from homozygous individuals for a variant allele at the $L D H-A 2 *$ locus having altered banding intensities that reflect a reduced level of activity of this allele. Following Shaklee $e t$ al. (1990), we designate this allele $* 100 Q L$.
Fig. $2 \mathrm{MDH}$ zymogram from brown trout muscle extracts showing phenotypic variation as a result of a previously unreported allele in the $s M D H-B 1,2 *$ isoloci. Genotype interpretations: a, $s M D H-B 1,2^{*}$ 100/100/100/100 (common phenotype); b, $s M D H-B 1,2 * 75 / 100 / 100 / 100$; c, $s M D H-B 1,2 * 75 / 75 / 100 / 100 ; \mathrm{d}, s M D H-$ $B 1,2^{*} 75 / 75 / 75 / 100$; e, $s M D H$ $B 1,2 * 75 / 75 / 75 / 75$.

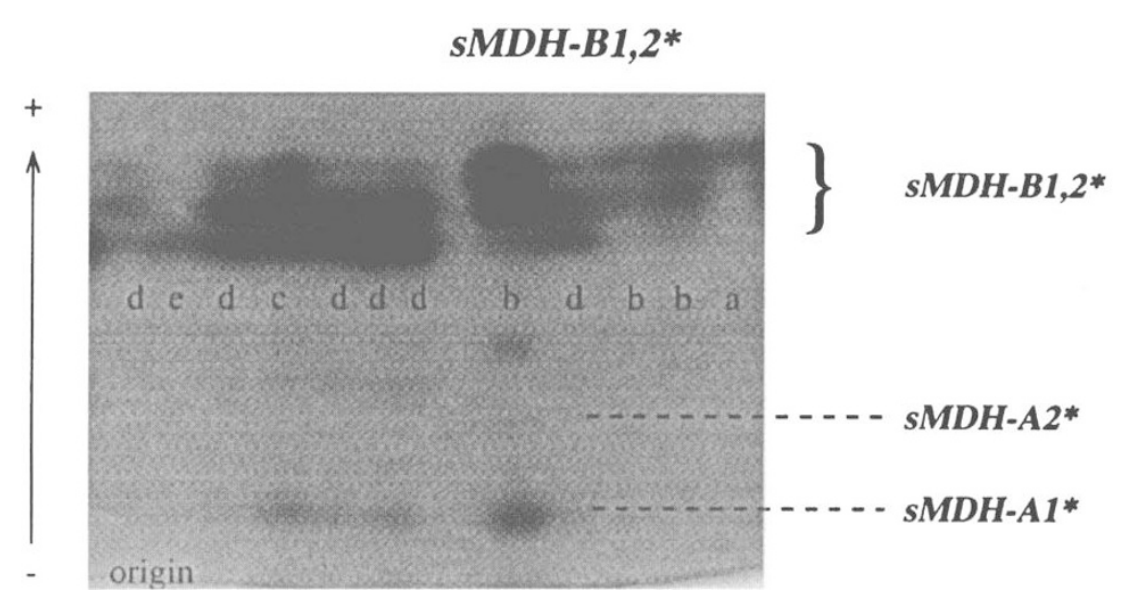




\section{Genetic variation within populations}

Allelic variation was detected at 25 of the 49 protein-coding loci examined (Appendix). Among individual populations, this overall polymorphism ranged from 0 to 36 per cent, and heterozygosity ranged from 0 to 6.1 per cent. Allelic variants $A D H^{*} 0, A C P^{*} 115, b G A L A-2 * 90, G P I-B 2 * 50, I D H P-$ $1 * 85, L G L * 90, a M A N * 90, s M D H-B 1,2 * 75, M E^{*} 140$, $M E P-3 * 90, P G M-1 * 80$ and $S O D * 120$ do not appear to have been reported previously in other countries. However, although side-by-side gel comparison was not made, our $s M D H-B 1,2 * 75, M E P-3 * 90$ and $S O D-1 * 120$ alleles seem to be equivalent to the previous rare alleles $M D H-3 * 80$ (Martinez et al.,
1993), $M E-4 * 75$ (Krieg \& Guyomard, 1985) and SOD-2*135 (Riffel et al., 1995).

Genotypes of five individuals from collection (11) Riutort Creek, and six from collection (22) River Mundo, differed particularly from other concurrently collected fish at these locations. Most notable was the fixation of the $L D H-C^{*} 90$ allele, typical of exogenous fish from Spanish hatcheries (GarcíaMarín et al., 1991) that was absent in other fish of these collections. Tests for gametic phase disequilibria $(D)$ were made with these collections, both including and excluding these 11 fish, as well as with collections from other areas where hatchery fish had been reported (Fig. 1, Table 1). Significant $D$-values were restricted to (11) Riutort Creek, and (22)

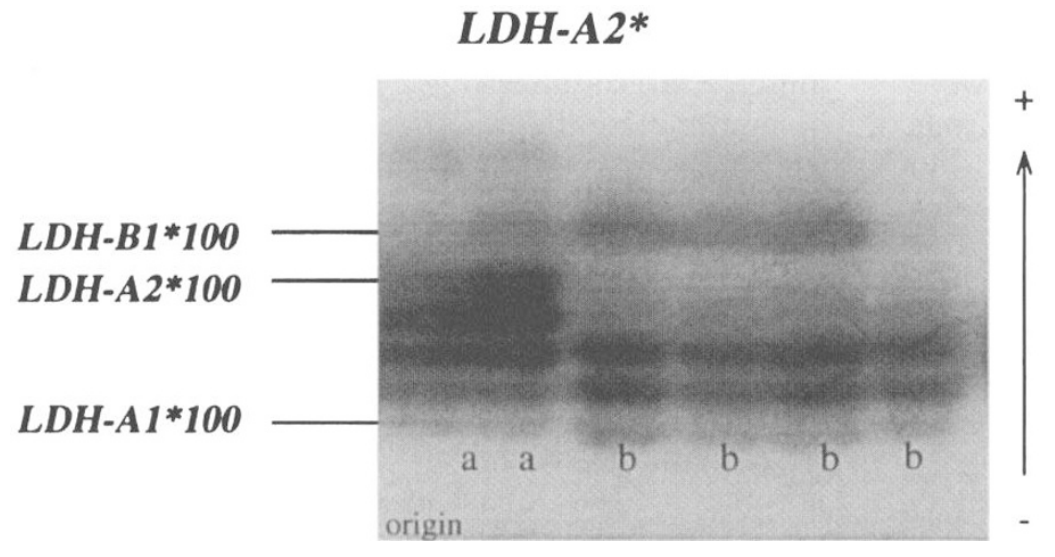

Fig. 3 LDH zymogram from brown trout muscle extracts showing a phenotypic variation interpreted as a variant allele at the $L D H-A 2 *$ locus (see text).

Table 1 Gametic phase disequilibrium analysis in populations of brown trout planted with hatchery-reared fish

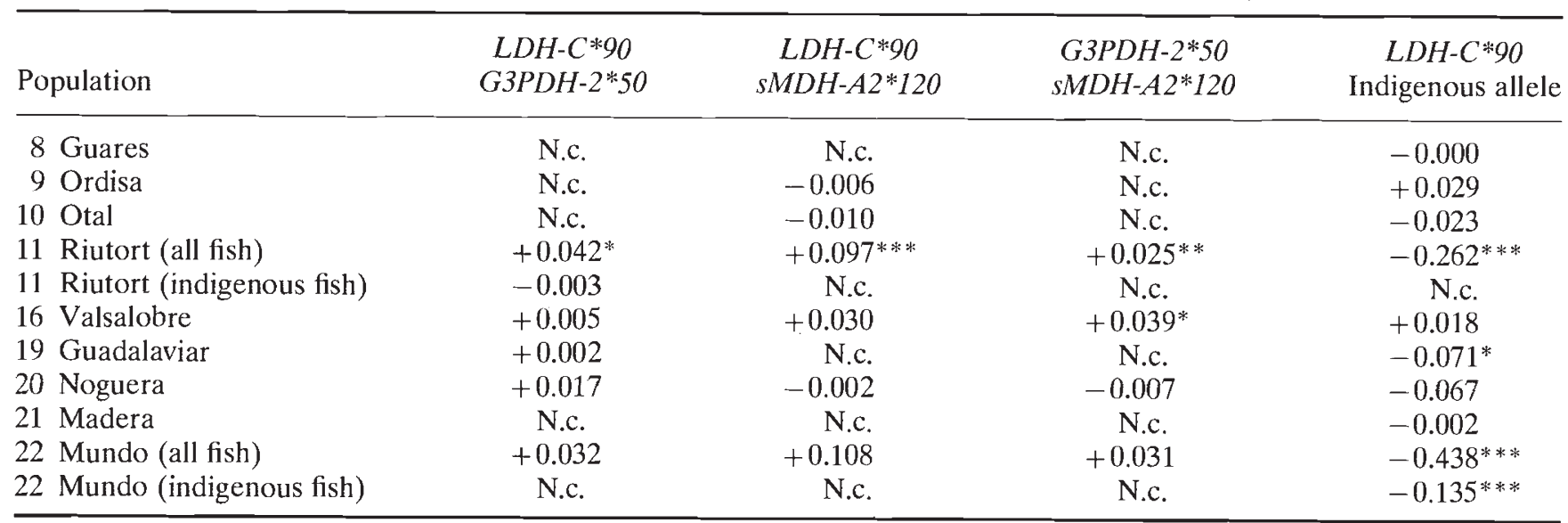

Single-test significance probabilities are: ${ }^{*} P<0.05,{ }^{*} P<0.01$, and ${ }^{* * *} P<0.001$.

Indigenous allele is: $A C P^{*} 115$ in population (8); $b G A L A-2 * 95$ in population (9); $I D H P-3 * 130$ in populations (10) and (22); $a M A N^{* 90}$ in populations (11) and (16); $A D H^{*} 0$ in populations (19) and (20); and $M E^{*} 140$ in population (21).

'N.c.' indicates that the disequilibrium parameter $(D)$ is not computable because one or both loci are monomorphic in the population. 
River Mundo, and all but one involved inclusion of these $11 \mathrm{fish}$; the other involved $\mathrm{LDH}-\mathrm{C}^{*} 90$ and $I D H P-3 * 130$ in the (22) River Mundo collection excluding these fish. These desequilibria are consistent with these 11 fish representing a distinct hatchery population. The (11) Riutort Creek and (22) River Mundo samples are therefore each listed twice in the Appendix, with and without these fish of apparent hatchery origin.

Tests for expected binomial (Hardy-Weinberg) genotypic frequencies within loci and other subsequent analyses of this study excluded these 11 fish of presumed hatchery origin. No significant deviations from expected Hardy-Weinberg genotypic frequencies $(P<0.05)$ were observed.

\section{Genetic variation among populations}

Large differences in allele frequencies were observed among populations (Table 2, Appendix). Frequencies of the *100 allele ranged from $0.0-1.0$ for eight loci $\left(C K-A 1^{*}, b G A L A-2^{*}, L G L^{*}, a M A N^{*}\right.$, $\left.M E^{*}, M E P-3^{*}, P E P L T^{*}, P G M-1^{*}\right)$ and the range exceeded 0.5 for 11 others. The magnitude of variation was apparent both in the significance of heterogeneity among samples for all loci but EST-2*, and in a level of significance less than 0.001 for all other loci except G3PDH-2*. Variant alleles, when present, tended to occur at fairly high frequencies; however, their distributions among streams within main rivers sometimes failed to show a clear pattern.

Table 2 Distribution of electrophoretically detectable gene diversity among Spanish populations of brown trout (standard errors in parentheses)

\begin{tabular}{|c|c|c|c|c|c|c|c|c|}
\hline \multirow[b]{3}{*}{ Locus } & \multirow{3}{*}{$\begin{array}{l}\text { Frequency } \\
\text { range of } \\
* 100 \text { allele }\end{array}$} & \multirow[b]{3}{*}{ NPOP } & \multicolumn{2}{|c|}{ Absolute gene diversity } & \multicolumn{4}{|c|}{ Relative gene diversity (\%) } \\
\hline & & & \multirow{2}{*}{$\begin{array}{c}\text { Total } \\
H_{\mathrm{T}}\end{array}$} & \multirow{2}{*}{$\begin{array}{c}\text { Within } \\
\text { populations } \\
H_{\mathrm{S}}\end{array}$} & \multirow{2}{*}{$\begin{array}{c}\text { Within } \\
\text { populations } \\
H_{\mathrm{S}} / H_{\mathrm{T}}\end{array}$} & \multicolumn{3}{|c|}{$\begin{array}{l}\text { Differentiation among } \\
\text { populations }\left(G_{\mathrm{ST}}\right)\end{array}$} \\
\hline & & & & & & $G_{\mathrm{SR}}$ & $G_{\mathrm{RD}}$ & $G_{\mathrm{DT}}$ \\
\hline$A C P^{*}$ & $0.75-1.00$ & 2 & 0.029 & 0.023 & 81 & 11 & 8 & 0 \\
\hline$A D H^{*}$ & $0.33-1.00$ & 2 & 0.098 & 0.039 & 40 & 0 & 55 & 5 \\
\hline$S A A T-4^{*}$ & $0.42-1.00$ & 4 & 0.063 & 0.036 & 57 & 23 & 19 & 1 \\
\hline$C K-A 1^{*}$ & $0.00-1.00$ & 18 & 0.497 & 0.127 & 26 & 2 & 8 & 64 \\
\hline EST-2* & $0.97-1.00$ & 2 & 0.006 & 0.005 & 97 & 1 & 2 & 0 \\
\hline$b G A L A-2^{*}$ & $0.00-1.00$ & 9 & 0.186 & 0.084 & 45 & 23 & 25 & 7 \\
\hline$b G L U A^{*}$ & $0.16-1.00$ & 12 & 0.205 & 0.129 & 63 & 16 & 17 & 4 \\
\hline$G P I-B 2^{*}$ & $0.22-1.00$ & 3 & 0.111 & 0.040 & 36 & 34 & 25 & 5 \\
\hline$G 3 P D H-2^{*}$ & $0.94-1.00$ & 4 & 0.018 & 0.017 & 96 & 1 & 2 & 1 \\
\hline$I D H P-1^{*}$ & $0.33-1.00$ & 1 & 0.054 & 0.019 & 34 & 34 & 28 & 4 \\
\hline$I D H P-2 *$ & $0.04-1.00$ & 7 & 0.185 & 0.052 & 28 & 15 & 48 & 9 \\
\hline$I D H P-3^{*}$ & $0.10-1.00$ & 10 & 0.174 & 0.100 & 58 & 28 & 12 & 2 \\
\hline$L D H-A 2^{*}$ & $0.06-1.00$ & 10 & 0.357 & 0.152 & 43 & 10 & 45 & 2 \\
\hline$L D H-C^{*}$ & $0.79-1.00$ & 11 & 0.135 & 0.101 & 75 & 11 & 11 & 3 \\
\hline$L G L^{*}$ & $0.00-1.00$ & 2 & 0.152 & 0.000 & 0 & 0 & 89 & 11 \\
\hline$a M A N^{*}$ & $0.00-1.00$ & 7 & 0.386 & 0.045 & 12 & 14 & 70 & 4 \\
\hline$s M D H-A 2^{*}$ & $0.86-1.00$ & 4 & 0.035 & 0.032 & 90 & 6 & 4 & 0 \\
\hline$s M D H-B 1^{*}$ & $0.02-1.00$ & 9 & 0.215 & 0.067 & 31 & 1 & 62 & 6 \\
\hline$s M D H-B 2^{*}$ & $0.34-1.00$ & 2 & 0.093 & 0.039 & 42 & 1 & 51 & 6 \\
\hline$M E^{*}$ & $0.00-1.00$ & 10 & 0.324 & 0.131 & 40 & 16 & 26 & 18 \\
\hline$M E P-3 *$ & $0.00-1.00$ & 5 & 0.224 & 0.040 & 18 & 2 & 79 & 11 \\
\hline$M P I-2^{*}$ & $0.22-1.00$ & 13 & 0.250 & 0.130 & 52 & 12 & 32 & 4 \\
\hline$P E P L T^{*}$ & $0.00-1.00$ & 5 & 0.169 & 0.017 & 10 & 1 & 78 & 11 \\
\hline$P G M-1^{*}$ & $0.00-1.00$ & 4 & 0.111 & 0.025 & 23 & 42 & 29 & 6 \\
\hline$S O D-1^{*}$ & $0.52-1.00$ & 3 & 0.081 & 0.053 & 66 & 12 & 18 & 4 \\
\hline Average & & & $\begin{array}{c}0.085 \\
(0.017)\end{array}$ & $\begin{array}{c}0.031 \\
(0.006)\end{array}$ & $\begin{array}{l}36 \\
(4)\end{array}$ & $\begin{array}{l}12 \\
(2)\end{array}$ & $\begin{array}{l}39 \\
(6)\end{array}$ & $\begin{array}{l}13 \\
(7)\end{array}$ \\
\hline
\end{tabular}

NPOP, number of populations with allelic variants.

$G_{\mathrm{SR}}$ differentiation between populations (streams) within main river, $G_{\mathrm{RD}}$ differentiation between main rivers within drainage and $G_{\mathrm{DT}}$ differentiation between drainages (Atlantic vs. Mediterranean). 
For instance, the similarities of (3) Carrión and (4) Pisuerga in the Duero, and (23) Genil and (24) Dilar in the Guadalquivir River, both pairs of collections each differing significantly only at the $b G L U A^{*}$ locus, contrast with the distinctness of (6) Gorrotola and (7) Santolatz separated within a common Cantabrian-flowing stream by only few kilometres, and differing significantly at six loci.

The gene diversity analysis (Table 2) reflected the individuality of the populations. Only 36 per cent of the total genetic variation was shared among populations. The largest proportion of the total variation (39 per cent) occurred among major rivers within the Atlantic and Mediterranean drainages, whereas smaller and approximately equal amounts of variation were allocated to populations within main rivers (12 per cent) and to differences between Atlantic and Mediterranean drainages (13 per cent). A single locus $C K-A 1^{*}$ is the primary contributor to the last value $\left(G_{\mathrm{DT}}=64\right.$ per cent), where the high frequency of the *115 allele which occurred in all Atlantic rivers $(0.89 \pm 0.19)$ contrasted with a much lower frequency in Mediterranean streams $(0.09 \pm 0.13)$.

Although the greater and stronger similarities in the UPGMA cluster analysis (Fig. 4) occurred between paired samples from common rivers (i.e. (23) Genil(24) Dilar, (19) Guadalaviar-(20) Noguera, (17) Linares-(18) Villahermosa, (3) Carrión-(4) Pisuerga), no broad geographical patterns were apparent. Populations from adjacent major rivers were no more similar to one another than those from more distant ones, and populations such as (2) Bubal, (6) Gorrotola, (11) Riutort, (12) Ter, and (14) Massanes appeared to be quite isolated from other collections. Confidence values of some of the branching points are low as a reflection of the distribution of the allelic variants (Table 2).

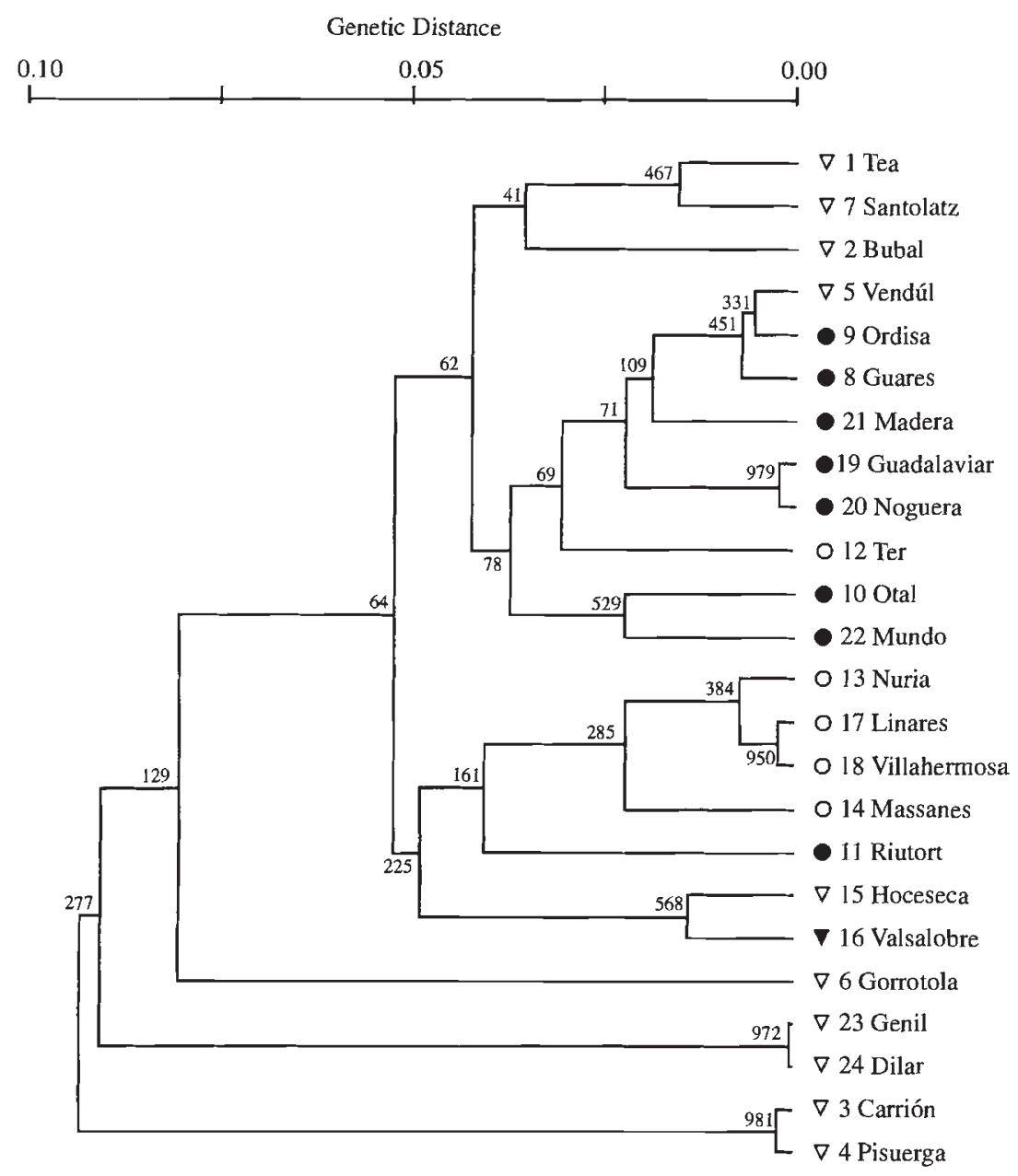

0.10 0.05
Fig. 4 UPGMA dendrogram summarizing the genetic relationships among Spanish populations of brown trout, based on Nei's genetic distance matrix. Filled symbol indicates presence of the $\mathrm{LDH}-\mathrm{C}^{* 90}$ allele in the population. The numbers at the forks indicate the number of times the branching point occurred among trees, out of 1000 bootstrapping replicates. The most stable associations are those branching points occurring in 950 or more replicates (Felsenstein, 1985). 
The projection of the first two principal coordinates of the genetic identity matrix (PCO, Fig. 5) also linked the similar paired populations from common rivers, and indicated such outlying individual populations as (6) Gorrotola, (11) Riutort and (14) Massanes. However, PCO added resolution not apparent in the cluster analysis by assigning positive values of coordinate 1 to populations of Atlantic drainages and negative values to the Mediterranean collections. In addition, the PCO projections plots tended to draw together most of those populations from areas where hatchery plants have been reported.

\section{Discussion}

Interpretation of the data of this study is limited by legally imposed sampling restrictions resulting in reduced accuracy and precision of allele frequency estimates based on five to 31 individuals. For instance, estimates of actual allele frequency values other than $0,0.10,0.20$, etc. would inevitably be distorted in a sample of 10 genes from five individuals. Such distortions also tend to bias downwards estimates of polymorphic loci and heterozygosity, and to inflate components of gene diversity. In spite of these limitations, the observed variation provides some useful insights into the genetic population

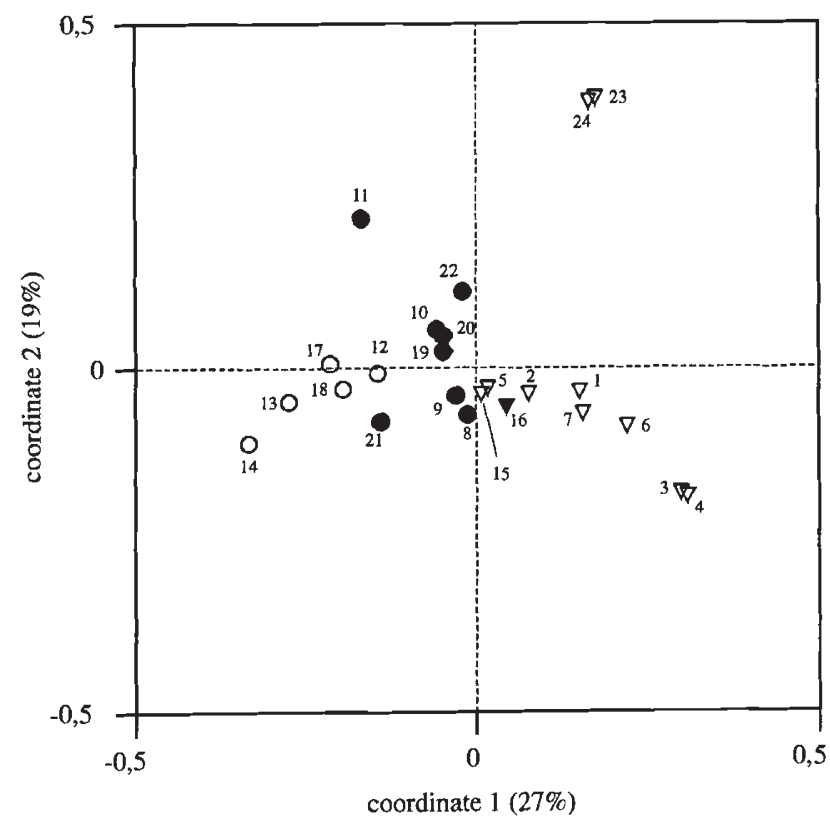

Fig. 5 Principal coordinates analysis of Spanish brown trout populations based on Nei's genetic identity matrix. Populations are projected onto the plane formed by the first two principal coordinates axes (symbols as in Fig. 4). structure of Iberian brown trout populations because of its qualitative nature, reinforced by the low levels of polymorphisms detected in most of the larger samples, i.e. (2) Bubal, (3) Carrión, (4) Pisuerga, (5) Vendúl, (6) Gorrotola, (11) Riutort, (15) Hoceseca, (17) Linares, (18) Villahermosa, (23) Genil and (24) Dilar.

\section{Influence of hatchery fish}

The exclusion from analyses of 11 fish of apparent hatchery origin or ancestry does not eliminate the possibility of introgression from hatchery fish among the remaining fish. The fixation of the $L D H-C^{*} 90$ allele in hatchery populations used in Spain and its apparent absence from Iberian populations prior to introductions of hatchery fish (García-Marín et al., 1991; Martinez et al., 1993; Morán et al., 1995) has provided a useful genetic marker for seeking such introgression. This characteristic allele of the 'modern race' of northern European brown trout (Hamilton et al., 1989) was observed only in populations from each of the areas of collection where hatchery fish had been reported. Other alleles occurring at appreciable frequencies $(>0.10)$ in Spanish hatchery stocks but rare in indigenous populations were also observed in these areas, including G3PDH-2*50, sMDH-A2*120 and sMDH-B1*80 (García-Marín et al., 1991; Martinez et al., 1993).

Cumulatively, these data strongly infer the presence of hatchery genes in these areas. Similar introductions of hatchery genes have been reported in Mediterranean French populations (Barbat-Leterrier et al., 1989). The lack of significant departures from Hardy-Weinberg expectations and only a single observation of gametic phase disequilibrium among wild fish collected in areas of hatchery releases suggests that these exotic genomes are assimilated within several random mating wild brown trout populations of Spain. Clearly, indigenous 'ancestral' and exogenous 'modern' lineages (Hamilton et al., 1989) have not evolved full reproductive isolation. Although the low frequencies of the introduced $L D H-C^{*} 90$ allele in each location (range $0.02-0.21$ ) reflect a persisting predominance of native genes in these areas, hatchery populations have completely displaced native ones in other areas of Spain (García-Marín et al., 1991).

\section{Patterns of genetic differentiation}

The high $G_{\mathrm{ST}}$ value $(0.64)$ indicates a particularly high genetic divergence among Spanish populations. The above-noted exaggeration of divergence because 
of small sample sizes is offset by reduced divergence through apparent introgression from a common exogenous population in nine collections. Consequently, this high value is considered to be biologically meaningful.

Some of this distinctness certainly reflects a highly restricted gene flow among populations and extensive genetic drift within them, typical also of brown trout studied in Scandinavia (Ryman, 1983) and the British Isles (Ferguson, 1989). In addition, the considerable number of previously unreported alleles in these populations is consistent with the opportunity for accumulation of genetic variation in this region that is not available to recently repopulated postglacial regions (Ferguson, 1989). Under these conditions, it is not surprising to find populations of rivers with unique alleles, resulting in the high degree of differentiation between main rivers within the Atlantic and Mediterranean drainages $\left(G_{\mathrm{RD}}=0.39\right)$. Such limited gene flow is also consistent with the general lack of geographical and genetic correspondence in the UPGMA cluster analysis, and with the low average heterozygosities $\left(H_{\mathrm{S}}=0.031\right)$ we observed. We propose that the brown trout in Spanish rivers have been isolated since the end of the Wurmian glaciation in northern Europe. We envisage the existence of larger and possibly anadromous populations during glacial times whose sizes and migratory potential became reduced as increased temperatures restricted them to upstream regions. In this sense, our $G_{\mathrm{RD}}$ value is nearly twice that observed among Spanish populations when anadromous fish are present $\left(G_{\mathrm{RD}}=0.21\right.$, Morán et al., 1995).

\section{Ancestral origins}

Another isolating component of Spanish populations is superimposed on that resulting from restricted migration and drift. A distinct separation between unstocked populations of Atlantic and Mediterranean drainages is apparent in the first principal coordinate (Fig. 5). This grouping implies the existence of subdivisions within the 'ancestral race' proposed by Hamilton et al. (1989). The interfacing of these groups in Iberian rivers further contributes to the overall heterogeneity $\left(G_{\mathrm{DT}}=0.13\right)$ in this region.

This distinctness between Atlantic and Mediterranean drainages is primarly a reflection of the respective predominance of the $C K-A I^{*} 115$ and $C K-A{ }^{*} 100$ alleles in Atlantic and in Mediterranean rivers. The 'Atlantic' subdivision is proposed to extend to unglaciated areas of the southern British
Isles and Brittany based on the predominance of the $C K-A 1^{*} 115$ allele and the $L D H-C * 100$ allele (the marker allele of the 'ancestral race') reported in unstocked populations in these areas (Krieg \& Guyomard, 1985; Hauser et al., 1991). The 'Mediterranean' subdivision is proposed to extend eastward through the Black and Caspian Seas based on the predominance of $C K-A 1^{*} 100$ and $L D H-C * 100$ throughout this area (Krieg \& Guyomard, 1985; Osinov, 1988; Barbat-Leterrier et al., 1989; Karakousis \& Triantaphyllidis, 1990).

Our hypothesis of distinct 'ancestral' subgroups of brown trout in Spain raises additional issues that cannot presently be resolved. The presence of high frequencies in the two Guadalquivir River samples $(23,24)$ of the $L D H-A 2 * 100 Q L$ and $M E P-3 * 90$ alleles found otherwise only in many (but not all) Mediterranean streams is puzzling. Perhaps these sampling locations represent areas of merging between Atlantic and Mediterranean groups, as suggested by similarities of other ichthyofauna (Doadrio, 1988; Bianco, 1991). The absence of similar data sets from other areas inhabited by native brown trout such as the Atlas Mountains in northern Africa, leaves open the possibility of the existence of additional major lineages. Conclusions derived from the present data provide a valuable framework for further insights into the evolutionary history of brown trout as information from nuclear loci and mitochondrial DNA (e.g. Bernatchez et al., 1992) accumulates to resolve these and other issues.

\section{Acknowledgements}

The authors wish to express their thanks to the Wildlife Agencies and forest guards of the Comunidades Autonomas of Andalucía, Aragón, Cantabria, Castilla-Leon, Castilla-La Mancha, Catalunya, Galicia, Valencia, and the Diputación Foral of Guipúzcoa for their help in collecting samples. The contribution of the A.E.M.S. memberships in those autonomous communities is also recognized. Special thanks to Miss Jane Bagge, Mr Pere Bonada and Dr Nils Ryman for their help during parts of this work. Dr F. M. Utter reviewed and made valuable contributions to the manuscript. This research was supported by a grant to J.L.G.M. from the CIRIT of the Autonomous Government of Catalunya (Spain).

\section{References}

BARBAT-LETERRIER, A., GUYOMARD, R. AND KRIEG, F. 1989. Introgression between introduced domesticated strains and mediterranean native populations of brown trout 
(Salmo trutta L.). Aquat. Living Resour, 2, 215-223. BEHNKE, R. J. 1986. Brown trout. Trout, 27, 42-47.

BERNATCHEZ, L., GUYOMARD, R. AND BONHOMME, F. 1992.

DNA sequence variation of the mitochondrial control region among geographically and morphologically remote European brown trout Salmo trutta populations. Mol. Ecol., 1, 161-173.

BIANCO, P. G. 1990. Potential role of the palaeohistory of the Mediterranean and Paratethys basins on the early dispersal of Euro-Mediterranean freshwater fishes. Ichthyol. Explor. Freshwaters, 1, 167-184.

CAMPTON, D. E. 1987. Natural hybridization and introgression in fishes. In: Ryman, N. and Utter F. (eds) Population Genetics and Fishery Management, pp. 161-192. University of Washington Press, Seattle.

CHAKRABORTY, R., HAAG, M., RYMAN, N. AND STÅHL, G. 1982. Hierarchical gene diversity analysis and its application to brown trout population data. Hereditas, 97, $17-21$.

DOADRIO, I. 1988. Delimitation of areas in the Iberian Peninsula on the basis of freshwater fishes. Bonn. zool. Beitr, 39, 11-128.

FELSENSTEIN, J. 1985. Confidence limits on phylogenies: an approach using the bootstrap. Evolution, 39, 783-791.

FERGUSON, A. 1989. Genetic differences among brown trout, Salmo trutta, stocks and their importance for the conservation and management of the species. Freshwater Biol., 21, 35-46.

GARCÍA-MARÍN, J. L., JORDE, P. E., RYMAN, N., UTTER, F. M. AND PLA, C. 1991. Management implications of genetic differentiation between native and hatchery populations of brown trout (Salmo trutta) in Spain. Aquaculture, 95, 235-249.

GOWER, J. C. 1966. Some distance proporties of latent root and vector methods in multivariate analysis. Biometrika, 53, 315-328.

HAMILTON, K. E., FERGUSON, A., TAGGART, J. B., TÓMASON, T., WALKER, A. AND FAHY, E. 1989. Post-glacial colonization of brown trout, Salmo trutta L.: LDH-5 as a phylogeographic marker. J. Fish Biol., 35, 651-664.

HAUSER, L., BEAUMONT, A. R., MARSHALL, G. T. H. AND WYATT, R. J. 1991. Effects of sea trout stocking on the population genetics of landlocked brown trout, Salmo trutta L. in the Conwy river system, North Wales, U.K. J. Fish Biol., 39, 109-116.

HERNÁNDEZ, J. L. AND WEIR, B. S. 1989. A disequilibrium coefficient approach to Hardy-Weinberg testing. Biometrics, 45, 53-70.
HINDAR, K., JONSSON, B., RYMAN, N. AND STÅHL, G. 1991. Genetic relationships among landlocked, resident, and anadromous Brown Trout, Salmo trutta L. Heredity, 66, 83-91.

KARAKOUSIS, Y. AND TRIANTAPHYLLIDIS, C. 1990. Genetic structure and differentiation among Greek brown trout (Salmo trutta L.) populations. Heredity, 64, 297-304.

KRIEG, F. AND GUYOMARD, R. 1985. Population genetics of French brown trout (Salmo trutta L.): large geographical differentiation of wild populations and high similarity of domesticated stocks. Génét. Sél. Évol., 17, 225-242.

MARTINEZ, P., ARIAS, J., CASTRO, J. AND SANCHEZ, L. 1993. Differential stocking incidence in brown trout (Salmo trutta) populations from Northwestern Spain. Aquaculture, 114, 203-216.

MORÁN, P., PENDAS, A.M., GARCIA-VAZQUEZ, E., IZQUIERDO, J.I. AND LOBON-CERVIA, J. 1995. Estimates of gene flow among neighbouring populations of brown trout. J. Fish Biol., 46, 593-602.

NEl, M. 1972. Genetic distance between populations. Am. Nat., 106, 283-292.

NE1. M. 1973. Analysis of gene diversity in subdivided populations. Proc. Natl. Acad. Sci. U.S.A., 70, 3321-3323.

osinov, A. G. 1988. Brown trout (Salmo trutta L., Salmonidae) in basins of the Black and Caspian seas: a population-genetic analysis. Genetika, 24, 2172-2186.

RICE, W. R. 1989. Analyzing tables of statistical tests. Evolution, 43, 223-225.

RIFFEL, M., STORCH, v. AND SCHREIBER, A. 1995. Allozyme varaibility of brown trout (Salmo trutta L.) populations across the Rhenanian-Danubian watershed in southwest Germany. Heredity, 74, 241-249.

RYMAN, N. 1983. Patterns of distribution of biochemical genetic variation in salmonids: differences between species. Aquaculture, 33, 1-21.

SHAKLEE, J. B., ALLENDORF F. W., MORIZOT, D. C. AND WHITT, G. S. 1990. Gene nomenclature for proteincoding loci in fish. Trans. Am. Fish. Soc., 119, 2-15.

SKAALA, $\varnothing$. AND NEVDAL, G. 1989. Genetic differentiation between freshwater resident and anadromous brown trout, Salmo trutta, within watercourses. J. Fish Biol., 34, 597-605.

SNEATH, P. H. A. AND SOKAL, R. R. 1973. Numerical Taxonomy. W. H. Freeman \& Co., San Francisco.

SOKAL, R. R. AND ROHLF, F. J. 1981. Biometry. 2nd edn. W. H. Freeman \& Co. San Francisco. 


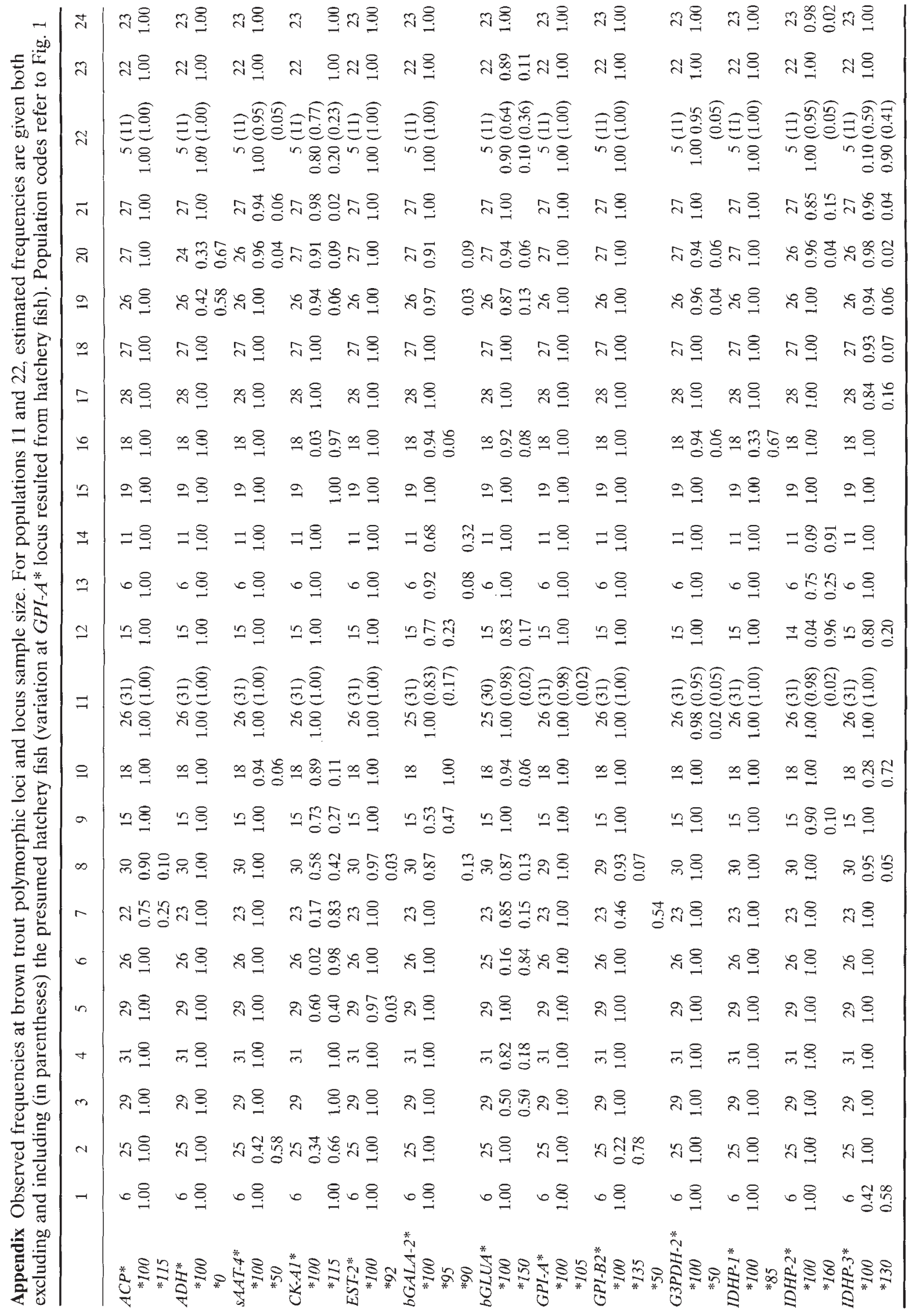




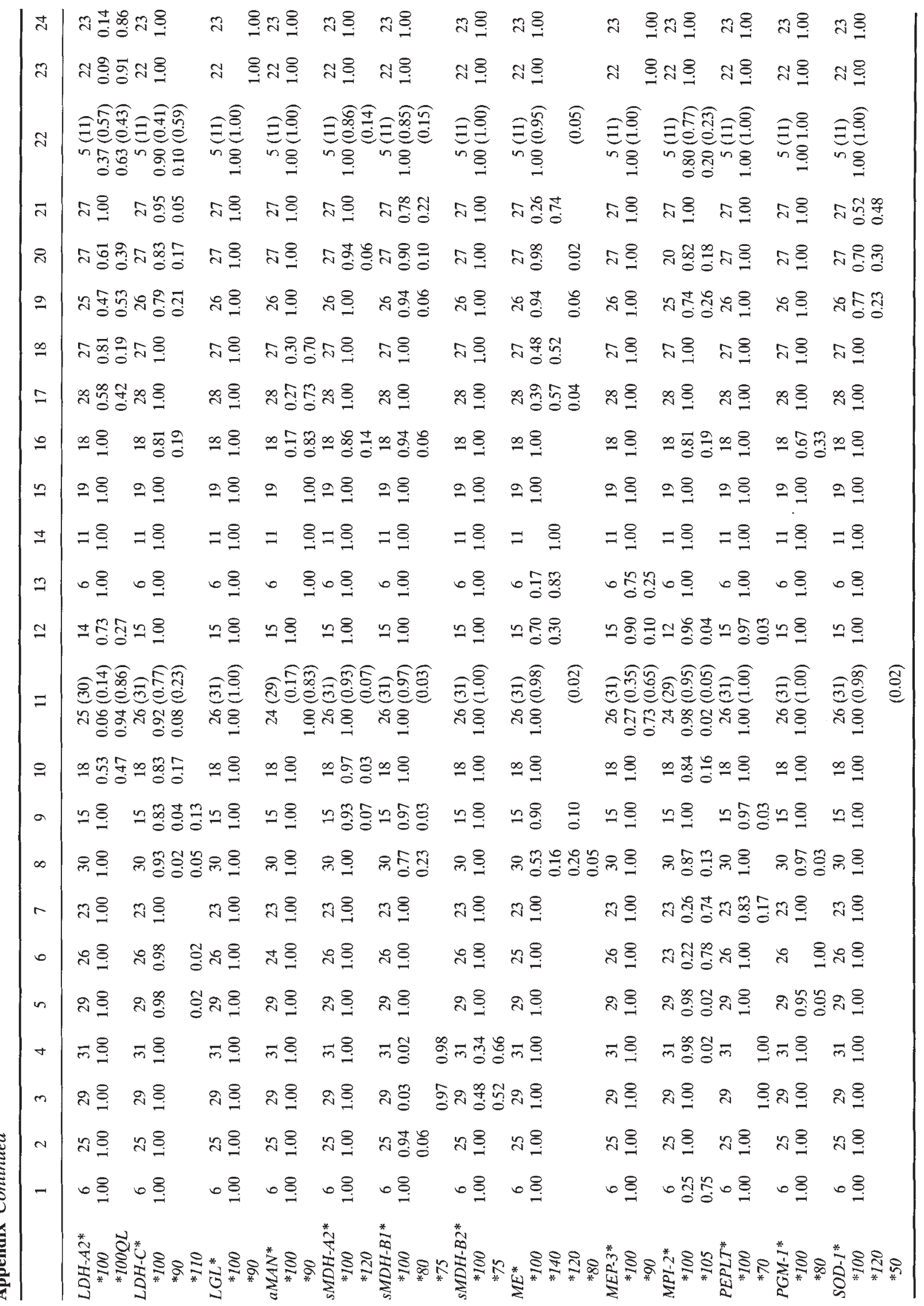

